\title{
PENGEMBANGAN PORTAL E-LEARNING SMK NEGERI 1 MANGGIS
}

\author{
Luh Joni Erawati Dewi, Ni Ketut Opayanti \\ Jurusan Manajemen Informatika, FTK, UNDIKSHA
}

\begin{abstract}
ABSTRAK
Portal E-learning SMK Negeri 1 Manggis adalah sebuah sistem yang dibuat untuk membantu serta mendukung proses pembelajaran baik pemberian materi maupun tugas secara online. Dengan adanya portal e-learning ini diharapkan dapat meningkatkan kadar interaksi pembelajaran antara peserta didik dengan guru karena memungkinkan terjadinya interaksi pembelajaran dari mana dan kapan saja. Selain itu, melatih siswa lebih mandiri dan aktif dalam mendapatkan ilmu pengetahuan, serta mempermudah penyimpanan materi pembelajaran. Perancangan sistem ini digambarkan dengan menggunakan DFD (data flow diagram) dan diimplementasikan dengan menggunakan Adobe Dreamwaver sebagai editor, Adobe Photoshop sebagi pengelola design, PHP sebagai script programing, dan MYSQL sebagai pengolah basis data.
\end{abstract}

Kata-kata kunci: portal, e-learning, SMK Negeri 1 Manggis

\begin{abstract}
E-learning Portal of SMK Negeri 1 Manggis is a system created to assist and support the learning process for the provision of material and assignments online. With the e-learning portal it is expected to increase the level of interaction between students and teachers, because the interaction of learning could be anywhere and anytime. In addition, e-learning can train students be more independent and active in getting the knowledge, as well as facilitate the storage of learning materials. The system is designed using DFD (data flow diagrams) and implemented using Adobe Dreamwaver as editor, Adobe Photoshop as a design manager, PHP as the programming scripts, and MySQL as database processing.
\end{abstract}

Keywords: portal, e-learning, SMK Negeri 1 Manggis

\section{PENDAHULUAN}

Ilmu pengetahuan dan teknologi selalu berkembang dan mengalami kemajuan, sesuai dengan perkembangan zaman dan perkembangan cara berpikir dan kebutuhan manusia. Berbagai media sebagai sumber dan penyedia informasi ilmu pengetahuan telah dikembangkan. Salah satunya adalah internet yang merupakan 
bentuk dari perkembangan teknologi informasi dan komunikasi yang manfaatnya sangat dirasakan bagi semua orang dan dalam segala bidang. Menjamurnya penggunaan internet benar-benar mengubah gaya hidup semua orang, mempengaruhi hampir setiap kegiatan. Kemajuan teknologi internet memberikan manfaat yang besar bagi dunia pendidikan. Internet sebagai media komunikasi dan informasi yang sangat memudahkan dalam pencarian informasi dalam suatu pembelajaran serta memudahkan dalam berkomunikasi.

Peningkatan mutu pendidikan pada sekolah merupakan suatu tuntutan. Oleh karena itu pembelajaran perlu dirancang dengan standard PAKEM (Pembelajaran Aktif, Kreatif, Efektif, dan Menyenangkan) sehingga peserta didik mampu menuangkan minat dan jiwanya pada aktivitas pembelajaran yang dijalankan. Suatu konsep dan strategi pendidikan yang berbasis teknologi informasi (TI) sangat diperlukan untuk menunjang atau membantu dalam proses belajar mengajar dalam menciptakan harmonisasi dan dinamika pembelajaran yang kreatif. Salah satu produk teknik informasi dan komunikasi untuk pembelajaran adalah $e$ learning.

Rosenberg (2001) dalam Yazdi (2012) menekankan bahwa :

e-learning merujuk pada penggunaan teknologi internet untuk mengirimkan serangkaian solusi yang dapat meningkatkan pengetahuan dan keterampilan.

Perbedaan Pembelajaran konvensional dengan e-learning yaitu pada pembelajaran konvensional, guru dianggap sebagai orang yang serba tahu dan ditugaskan untuk menyalurkan ilmu pengetahuan kepada pelajarnya. Sedangkan di dalam pembelajaran e-learning, fokus utamanya adalah pelajar. Suasana pembelajaran e-learning akan memaksa pelajar memainkan peranan yang lebih aktif dalam pembelajarannya. Pelajar membuat perancangan dan mencari materi dengan usaha, dan inisiatif sendiri.

SMK Negeri 1 Manggis merupakan salah satu sekolah menengah kejuruan yang cukup terkenal di Kabupaten Karangasem, yang memiliki empat jurusan yaitu jurusan Teknik Komputer dan Jaringan, Akomodasi Perhotelan, Teknik Sepeda Motor, dan Teknik Kendaraan Ringan. Selama ini semua proses 
pembelajaran di SMK Negeri 1 Manggis masih bersifat konvensional, dengan kata lain bahwa proses belajar mengajar antara siswa dengan guru hanya dapat dilakukan dengan syarat terjadinya pertemuan antara siswa dengan guru di dalam kelas. Jika pertemuan antara siswa dengan guru tidak terjadi atau guru yang bersangkutan tidak hadir dan waktu pembelajaran yang dibatasi pihak sekolah, maka secara otomatis proses pembelajaran pun akan terhambat. Keadaan seperti ini dapat menghambat proses pembelajaran atau penyampaian materi serta pemberian tugas dari guru ke siswa di SMK Negeri 1 Manggis yang dapat berakibat berkurangnya pemahaman siswa terhadap suatu materi pelajaran. Oleh karena itu perlu dibuat suatu aplikasi $e$ learning berbasis web yang dapat diakses kapan saja dan di mana saja sehingga dapat mendukung dan membantu proses pendidikan di SMK Negeri 1 Manggis. Penerapan e-learning diharapkan mampu memberikan solusi yang baik dan tepat guna bagi guru dan siswa. Berkembangnya e-learning harus diimbangi pula dengan adanya portal e-learning. Portal e-learning merupakan pintu gerbang yang dilalui guru dan siswa untuk memulai aktivitas dan penggunaan fasilitas-fasilitas yang ada di dalam sistem seperti download materi, upload tugas, dan yang lainnya.

E-learning merupakan aplikasi berbasis web, yang berjalan pada komputer server dan diakses menggunakan program web browser (Internet Explorer, Opera, Mozilla, dan lain-lain) pada komputer client. Komputer server bisa dipasang di mana saja baik di jaringan lokal (Intranet) maupun jaringan global (Internet). Dosen dan mahasiswa dapat mengakses sistem bisa dari berbagai tempat baik dengan koneksi Intranet maupun Internet (Cole, 2005).

E-learning bisa diimplementasikan dalam lingkungan apapun misalnya sekolah, industri, pemerintah atau desa, dan mungkin tersedia dalam berbagai level keahlian. Banyak bentuk dari e-learning. Yang paling sederhana adalah siswa bisa berkomunikasi dengan guru lewat email, atau yang lebih kompleks kuliah video konferens, atau total perkuliahan yang diselenggarakan universitas melalui internet(pendidikan jarak jauh).

Rivera (Rivera \& Rowland, 2007) mengungkapkan pengalaman belajar yang kuat dan tahan lama (powerful) dapat dicapai dengan keterlibatan aktif dalam setting otentik dan adanya interaksi yang bermakna dengan orang lain. Selain itu, faktor 
emosi dan pengalaman unik bisa menjadikan pembelajaran tahan lama. Pada area $e$ learning, fleksibilitas merupakan hal positif dari pengalaman pembelajaran. Dalam e-learning, diharapkan terjadinya interaksi yang lebih bersifat real time, lebih banyak komunikasi dengan profesor/pembimbing, dan perlunya bimbingan komputer.

\section{METODOLOGI}

Dalam mengembangkan sistem ini, dilakukan langkah-langkah sesuai dengan prosedur pengembangan perangkat lunak, yaitu: melakukan analisis kebutuhan, membuat desain/rancangan sistem, melakukan coding, kemudian implementasi dan uji coba.

Analisis kebutuhan dilakukan dengan pengumpulan data dengan menggunakan metode kepustakaan yaitu dilakukan dengan cara membaca buku/jurnal yang berhubungan dengan e-learning. Selain itu, juga dilakukan wawancara dengan guruguru pengajar di SMKN I Manggis.

Langkah berikutnya dalam mengembangkan sistem ini adalah membuat rancangan system.

Untuk penggambaran rancangan sistem, digunakan Data Flow Diagram (DFD) dan diagram konteks. Diagram konteks adalah diagram yang terdiri dari suatu proses yang menggambarkan ruang lingkup suatu sistem. Diagram ini akan memberikan gambaran secara umum dari suatu sistem (Ladjamudin, 2005). Diagram konteks merupakan gambaran paling umum dari sistem yang memperlihatkan interaksi (input berupa data dan output berupa informasi) antara sistem dan entitasnya. Dalam portal e-learning SMK Negeri 1 Manggis, terjadi suatu interaksi atau hubungan antara sistem dengan entitas yaitu administrator, guru, dan siswa, dimana hubungan tersebut dapat digambarkan dengan diagram konteks seperti terlihat pada Gambar 1.

JPTK, UNDIKSHA, Vol. 10, No. 2, Juli 2013 : 91 - 98 


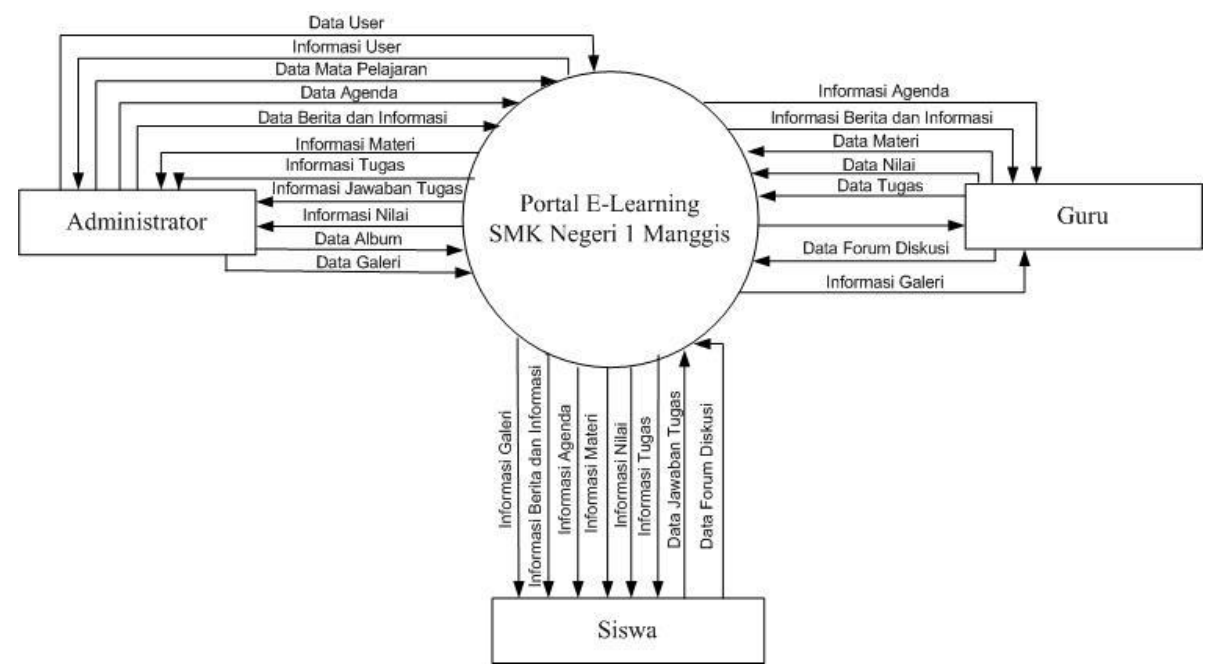

Gambar 1. Diagram Konteks

\section{HASIL DAN PEMBAHASAN}

Portal e-learning SMK Negeri 1 Manggis ini digunakan oleh tiga user yaitu administrator, guru dan siswa. Administrator dapat memanipulasi data user, data mata pelajaran, data agenda, data berita dan informasi, data album, dan data galeri, melihat data materi, nilai, tugas, dan jawaban tugas. Untuk dapat menggunakan sistem ini, guru dan siswa dibuatkan username dan password oleh administrator terlebih dahulu. Guru dapat mengubah profil kecuali username, mengubah password, memanipulasi data materi, tugas, serta nilai sesuai mata pelajaran yang diajarkan, mendownload jawaban tugas dari siswa, melihat agenda, galeri, berita dan informasi, serta mengisi forum diskusi. Siswa dapat mengubah profil kecuali username, ubah password, download materi, tugas, dan nilai, upload jawaban tugas, lihat agenda, galeri, dan berita dan informasi, serta mengisi forum diskusi.

Untuk dapat melakukan pengelolaan terhadap sistem, administrator harus masuk ke halaman administrator dengan login terlebih dahulu pada bagian login administrator. Setelah melakukan proses ini, akan muncul halaman awal administrator. Menu-menu yang terdapat dalam halaman administrator, yaitu menu beranda, manajemen user dengan sub menu input data guru dan input data siswa, agenda, berita dan informasi, profil saya, E-learning dengan sub menu manipulasi mata pelajaran, data materi, data soal, data tugas, dan data nilai, album, galeri foto, 
forum diskusi serta ubah password. Adapun halaman awal administrator dapat dilihat pada Gambar 2. Gambar 3 adalah halaman utama untuk administrator. Pada halaman ini administrator dapat melakukan berbagai fungsinya.

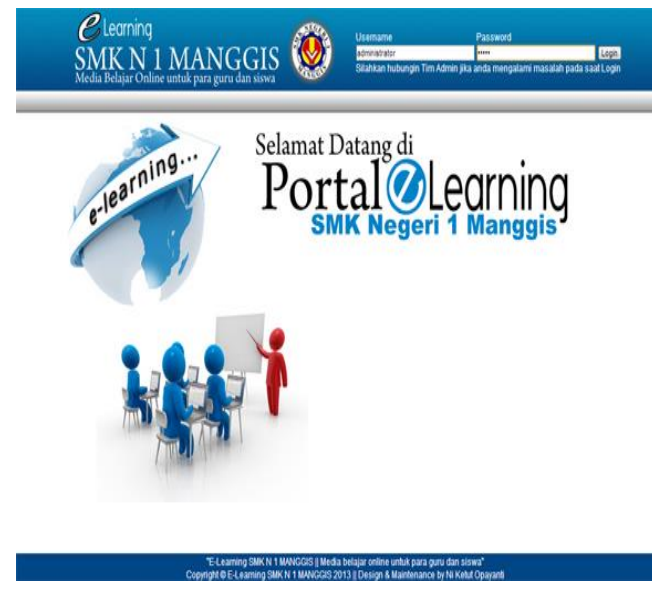

Gambar 2. Halaman awal administrator

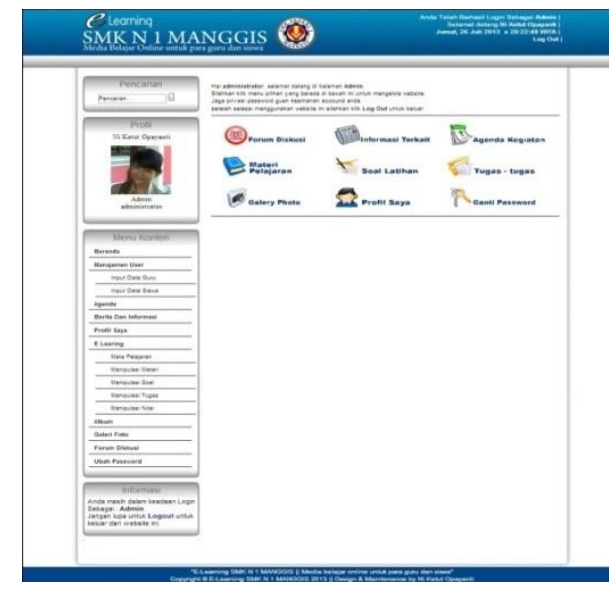

Gambar 3. Halaman utama administrator

Halaman guru muncul setelah guru melakukan proses login. Menu-menu yang terdapat dalam halaman guru yaitu menu beranda, agenda, berita dan informasi, profil saya, E-learning dengan sub menu manipulasi materi, manipulasi soal, manipulasi tugas, dan manipulasi nilai, galeri foto, serta forum diskusi. Adapun halaman awal guru dapat dilihat pada Gambar 4. Gambar 5 adalah halaman untuk guru untuk memanipulasi data materi (menyimpan materi).

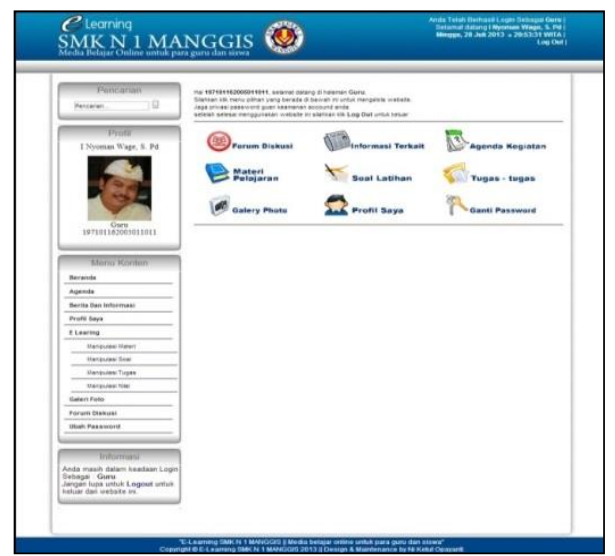

Gambar 4. Halaman awal guru

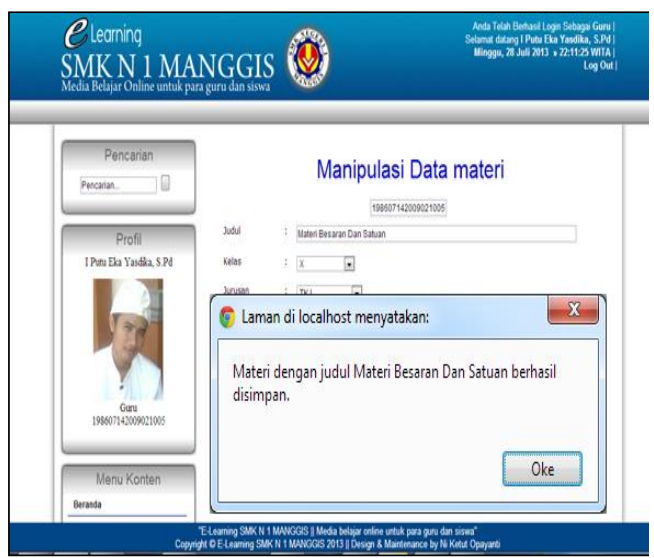

Gambar 5. Halaman manipulasi data materi 
Halaman siswa akan muncul setelah siswa melakukan proses login. Menumenu yang terdapat dalam halaman siswa yaitu menu beranda, agenda, berita dan informasi, profil saya, E-learning dengan sub menu tugas, download materi dan download nilai, galeri foto, serta forum diskusi. Adapun halaman awal siswa dapat dilihat pada Gambar 6.

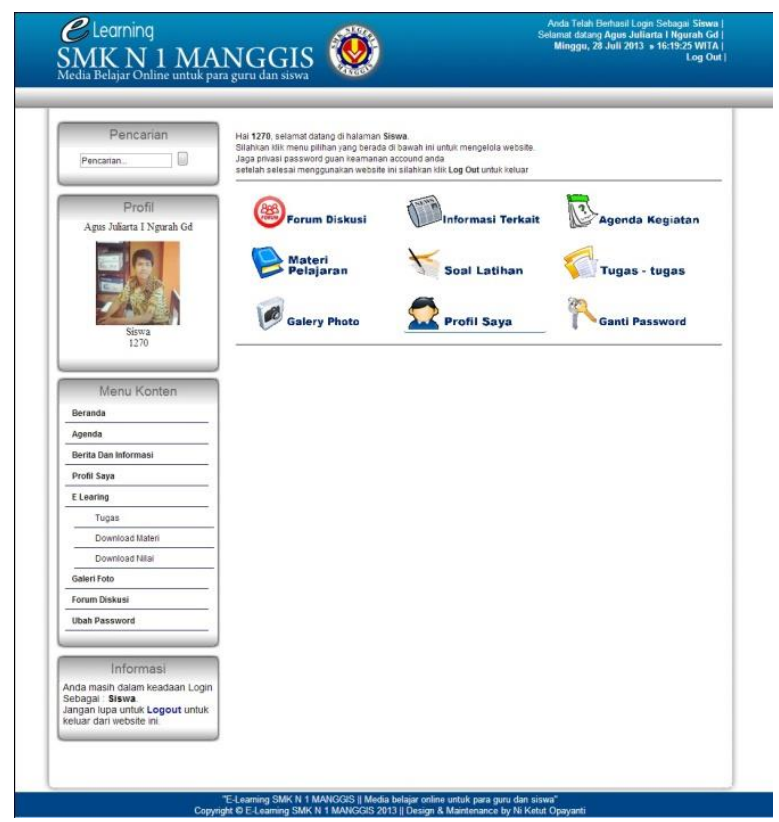

Gambar 6. Halaman awal siswa

\section{PENUTUP}

Dari uraian di atas dapat disimpulkan bahwa telah dibuat rancang bangun Portal e-learning SMK Negeri 1 Manggis yang terdiri dari rancangan sistem, rancangan basis data, dan rancangan antarmuka. Rancangan sistem digambarkan dengan menggunakan DFD (data flow diagram) yang diawali dengan membuat diagram konteks. Dari diagram ini terlihat bahwa pengguna sistem ada tiga yaitu admin, guru dan siswa. Adapun proses yang terjadi di dalamnya adalah login pengguna, manipulasi data, upload materi, download materi, akses informasi dan proses pencarian informasi. Untuk rancangan basis data, digunakan beberapa tabel 
yaitu tabel mata pelajaran, tabel user, tabel guru, tabel siswa, tabel agenda, tabel album, tabel galeri, tabel berita, tabel nilai, tabel jurusan, tabel jurusan bagian, tabel kelas, tabel materi, tabel tanggapan, tabel topik, tabel upload, dan tabel soal. Untuk rancangan antarmuka sistem terdiri dari beberapa rancangan utama yaitu rancangan antarmuka halaman siswa, rancangan antarmuka halaman guru, dan rancangan antarmuka halaman administrator.

Telah diimplementasikan sebuah Portal e-learning SMK Negeri 1 Manggis dengan menggunakan beberapa software. Adobe Dreamwaver digunakan sebagai editor, Adobe Photoshop sebagai pengelola design dan PHP sebagai script programing. MYSQL digunakan sebagai pengelola basis data.

Portal e-learning SMK Negeri 1 Manggis ini dibangun dengan tujuan dapat membantu serta mendukung dalam kegiatan belajar mengajar yang meliputi proses download materi dan upload tugas. Sistem ini masih banyak terdapat kekurangan. Untuk ke depannya, bagi yang ingin mengembangkan lebih lanjut diharapkan menambah ulangan online, kuis online, live chat dan yang lainnya yang mungkin bisa lebih menyempurnakan portal ini.

\section{DAFTAR PUSTAKA}

Cole, J. 2005. Using moodle. First Edition. California - USA: O'Reilly Media, Inc.

Ladjamudin, Al-Bahra Bin. 2005. Analisis dan Desain Sistem Informasi. Yogyakarta: Graha Ilmu.

Rivera, B. \& Rowland, G. 2007. Powerful e-learning: A preliminary study of learner experiences. Merlot Journal of Online Learning and Teaching, 4(1) 14-23.

Tersedia pada http://jolt.merlot.org/vol4no1/rowland0308.pdf. Tanggal akses 9 Nopember 2010.

Usadha, Made Ariana. 2010. Portal E-Learning Jurusan Manajemen Informatika. Tugas Akhir (tidak diterbitkan). Jurusan Manajemen Informatika, Undiksha.

Yazdi, Mohammad. 2012. "E-Learning Sebagai Media Pembelajaran Interaktif Berbasis Teknologi Informasi” Jurnal Ilmiah Foristek, Volume 2, Nomor 1 (hlm. 145-147). 